INTERDISCIPLINARIA ARCHAEOLOGICA

\title{
Landscape Analysis of a Battlefield of the Austro-Prussian War of 1866 near Hospital Kuks
}

\author{
Matouš Holas ${ }^{1 *}$ \\ ${ }^{I}$ Department of Archaeology, Philosophical Faculty, University of Hradec Králové, Rokitanského 62, 50003 Hradec Králové 3, Czech Republic
}

\section{A R TICLE INFO}

Article history:

Received: $5^{\text {th }}$ January 2021

Accepted: $3^{\text {rd }}$ May 2021

DOI: http://dx.doi.org/10.24916/iansa.2022.1.6

Key words:

landscape analysis

Austro-Prussian War of 1866

battlefield archaeology

non-destructive research

\begin{abstract}
$A B S T R A C T$
The article presents the possibilities of landscape analysis based on historical and cartographic sources. The methods and procedures used produced important spatial information about a specific battlefield from the second half of the $19^{\text {th }}$ century. This type of non-destructive research is for the first time applied to a battlefield of the Austro-Prussian War of 1866 in the Hradec Králové region. The results of the analysis helped to find a place for a geophysical survey, which confirmed the location of a relic of field fortifications for the Austrian artillery near the baroque Hospital Kuks near Jaroměr. The results provide an important example for the implementation of similar methods in the research on modern battlefields in the Czech Republic.
\end{abstract}

\section{Introduction}

Archaeology of the Austro-Prussian War of 1866 is a new research topic from recent years. Battlefield archaeology is usually targeted at the period from the $15^{\text {th }}$ to the $18^{\text {th }}$ centuries, but the research dedicated to the late $19^{\text {th }}$ and $20^{\text {th }}$ centuries represents one of the most dynamically developing sub-disciplines in the Czech Republic in the last two decades (Krajíc et al., 2017). While the origins of the archaeological study of modern battlefields in the Czech Republic date back to the early $20^{\text {th }}$ century, large-scale systematic and interdisciplinary research projects have been conducted since the 1980 s, using a wide spectrum of modern technologies: aerial photography, airborne laser scanning and metal-detector survey (Matoušek, 2017). Battlefield or Conflict Archaeology has been developing very dynamically in the last three decades and it brings many new research questions (and aims), both in the Czech Republic and elsewhere in Europe (Matoušek, Sýkora, 2018; Preusz, 2019).

For example, archaeologists explored a battlefield landscape from the early $19^{\text {th }}$ century on the defence line

*Corresponding author. E-mail: matous.holas@uhk.cz of the War of the Sixth Coalition (1813-1814) against Napoleon. Thirty-five field fortifications, documented by written sources, were localised and described on the right bank of the Ohře River between Postoloprty and Budyně nad Ohř́. Twenty-one relics were detected on site, sixteen locations were discovered by aerial prospecting, two fortifications were examined with the help of test trenches, and in three cases the fortifications were preserved thanks to later buildings and a church with a cemetery (Smrž, Hluštík, 2007). Another artillery fortification, detected near the fortified town of Terezín, was built on the opposite bank of the river Elbe in the mid- $19^{\text {th }}$ century. The relics were documented by airborne laser scanning in 2011. This method clearly showed the traces of defunct earthen ramparts and ditches as well as a dense network of former roads and linear earthworks, some of which may have been related to the urban fortification (Gojda et al., 2011).

Archaeologists have studied the 1866 war relics since 2003, mainly due to intensified building activity on battlefields, which mostly disturbed war graves (Holas, 2017). The main research aims, topics and archaeological questions concerning the Austro-Prussian War of 1866 were for the first time comprehensively presented only two years ago (Holas, 2019). The reconstructed 1866 historical 
landscape has not yet been analysed by the methods of nondestructive survey, so the results presented in this article might be a source of information for future research. The study site was chosen on the basis of a non-destructive survey of battlefields at Hradec Králové, conducted by a group of researchers from the Department of Archaeology, Philosophical Faculty, University of Hradec Králové. This survey is intended to acquire spatial data from the terrain and to describe the shape and dimensions of relics of Austrian field fortifications for artillery, which are preserved not only on the battlefield at Hradec Králové (Hejhal, Holas, 2018).

Geographic information technologies (GIS) were employed in non-destructive research to create a spatiallyaccurate representation of the 1866 battlefield landscape which is situated near Hospital Kuks in the Hradec Králové region. GIS provides the tools and methods to accurately create digital models of historical landscapes. These tools enable the visualisation and geospatial analysis of the landscapes and significant historical events of the 1866 war, greatly enhancing the understanding of temporal and spatial interactions between these events and the landscape in which they occurred.

The results of the investigation have elucidated the appearance of the historical landscape at the time of the
Austro-Prussian War of 1866 and, in particular, the artillery clash on 30 June of that year. The geospatial analysis will be a help for future archaeological research thanks to the exact terrain data. The methods used and the interdisciplinary approach will also be applicable to other investigations seeking to recreate historical landscapes of the 1866 war.

\section{Study site and methodology}

The study area is located northwest of the town of Jaroměr in Trutnov district in eastern Bohemia and encompasses the present-day municipalities of Choustníkovo Hradiště (Gradlitz), Žireč (Surz), Kašov (Kašow), Nový Kašov, Zaloňov (Salney), Brod (Prode) and Vlčkovice v Podkrkonoší (Wölsdorf). The total area of the study site is $2 \mathrm{ha}$. In the middle of the study site, there are the municipalities of Stanovice (Stangendorf), Slotov (Schlotten) and Kuks (Kukus) with the buildings and gardens of its baroque hospital (Figure 1A).

In terms of geology, the studied area belongs to the Bohemian Cretaceous Basin. The northern part is dominated by sandstones and siltstones. Holocene deposits are located near the river Elbe. These deposits include alluvial and organogenic sediments and blown sands. The area is mostly
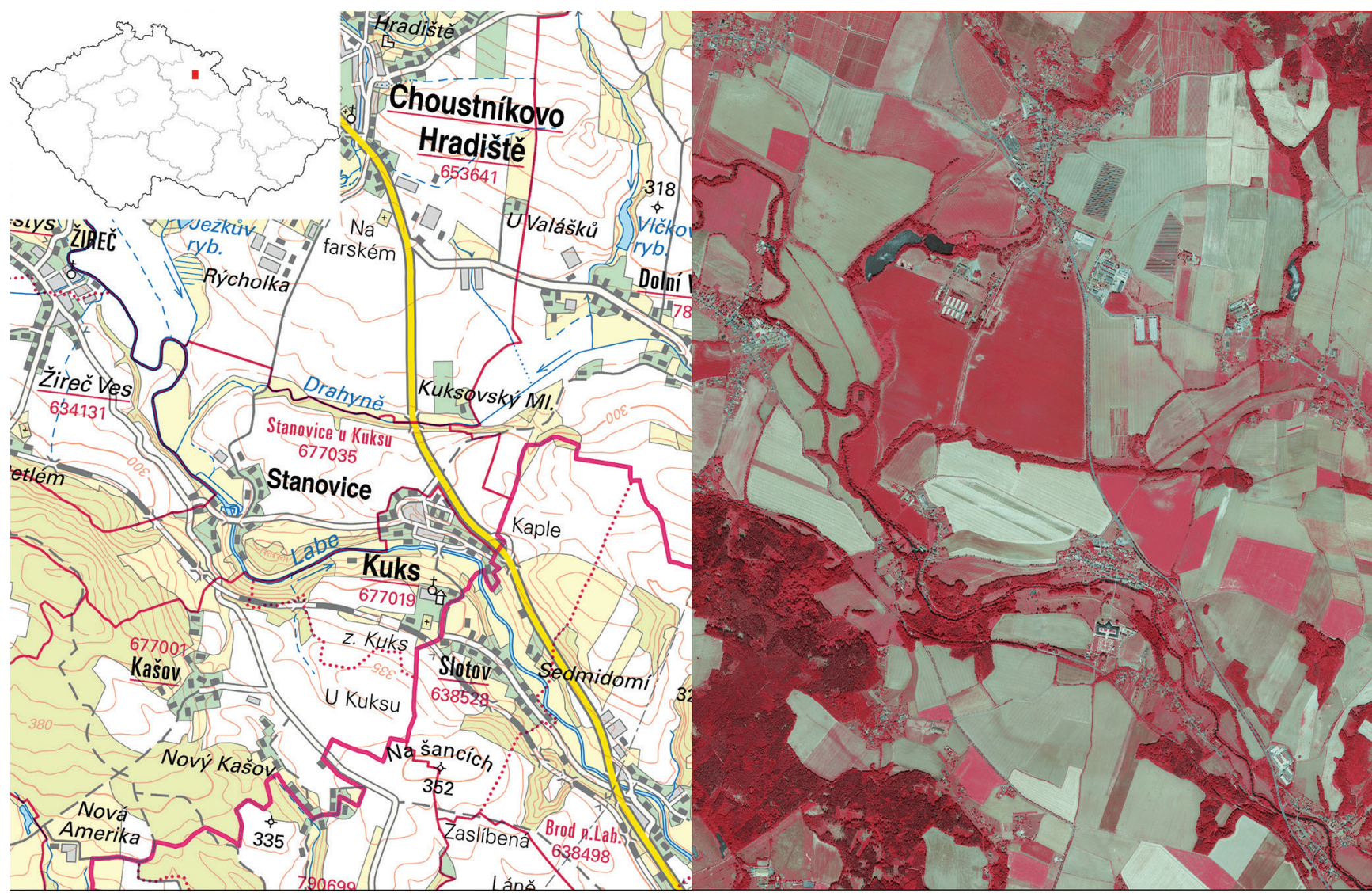

政

(A)

Figure 1. Study site: A: Localisation of the study site. The map scale is 1:50,000. Sources: Web Map Service, Czech Office for Surveying, Mapping and Cadastre; B: Colour infrared orthophoto from 2017, depicting the state of vegetation. Sources: Web Map Service, Czech Office for Surveying, Mapping and Cadastre, Forest Management Institute. 
formed by aeolian sediments (loess, loess clay), the so-called colluvium, glacial, fluvioglacial and terrace sediments. In the north, there are arkoses, sandstones, conglomerates, debris, siltstones, shales, melaphyres or rhyolites from the Late Palaeozoic period (Geoportal CENIA).

Among the soils, brown soils predominate. Around the river we can detect alluvial soils, the original plant stands here being floodplain forests and valley meadows. The northern part of the area is dominated by medium to lower quality soils - acid brown soils and brown soils. These soil types typically occur at higher altitudes with a higher proportion of forest stands (Novák et al., 1992).

A central and unifying geographic feature of the study area is the river Elbe paralleled by a railway line, which divided the study site into two parts. The terrain relief is more rugged in the southern part of the studied area, on the right bank of the Elbe, which is covered with loess and was therefore preferred for its fertility in agricultural prehistory. Two distinct terrain locations are visible on this bank of the river. The first location reaches $426 \mathrm{~m}$ asl and is situated above the village of Kašov. The other, less-pronounced, terrain location is situated south of the village of Slotov and reaches $353 \mathrm{~m}$ asl. The second location is more interesting from the perspective of a terrain analysis because it overlooked the left bank of the Elbe River. The left bank of the Elbe is formed by its tributaries and by the lowland floodplain. The terrain is only ragged southeast of the village of Choustníkovo Hradiště and north of the village of Žireč. The study area is predominantly covered with a vegetation in the form of wooded and grassy areas, which copy the floodplain terrain of the river Elbe and its tributaries (Figure 1B).

Kuks village was founded by Count Franz Anton von Sporck as a small spa, which began to operate between 1692 and 1695. Count Sporck moved his residence from the castle in Choustníkovo Hradiště to this place and Kuks soon became a true spa town. As a small town, Kuks is marked on Müller's map of Bohemia from 1720. Later, on the opposite right bank of the river, Sporck built a monastery of Merciful Brothers with a hospital (Preiss, 2003, p.323). Hospital Kuks and the surrounding vicinity have not experienced major anthropogenic modifications, so the historical landscape is mostly preserved to this day. One significant anthropogenic intervention was the construction of a major road between the towns of Jaroměr and Trutnov in the second half of the $20^{\text {th }}$ century. A large part of the original field roads, wooded plots and grassy meadows disappeared from the landscape of the study site between 1840 and 1950 (Fanta, 2015). Hospital Kuks was declared a National Cultural Monument of the Czech Republic in 1995 and now, after an extensive reconstruction, it is an extremely popular tourist attraction.

Data sources include historical and cartographic records, high resolution orthophotographs, constant value raster grids, and LIDAR data. The landscape analysis of military terrain was created utilising the system categories of the American Battlefield Protection Program KOCOA, in order to describe the defining features of the battlefield. KOCOA is an acronym which stands for Key Terrain, Obstacles, Cover and
Concealment, Observation and Fields of Fire, and Avenues of Approach and Retreat. The KOCOA analysis provides an established method for identifying the critical defining features of a battlefield and determining the influence of the landscape on the ephemeral battle events (Maio et al., 2013).

All data were processed in the ArcGIS software for the depiction of geographic information. GIS software provides a set of versatile tools that enable the visualisation and interpretation of data in a variety of ways. It displays data in a way that is quickly understood and easily shared, and its use enables a variety of questions and problems to be addressed. Recently, GIS has been successfully employed in the study of important historical events through the landscapes in which they occurred (Knowles, 2005). Over the past decade, numerous investigations have employed GIS in historical landscape reconstruction and military terrain analysis. Historical GIS was successfully employed to reconstruct and analyse the landscape of the American Civil War Battle of Gettysburg. That investigation created a digital representation of the historical terrain and carried out a viewshed analysis providing valuable insights into the influence of the military landscape on the battle's outcome.

The base map was created in GIS utilising the maps of the Second Military Survey (1851-1852, map scale 1:28,800), Imperial Obligatory Imprints of the Stable Cadastre (1840-1841, map scale 1:2,880) and the 1866 Prussian map Plan des Gefechtsterrains bei Gradlitz (map scale 1:25,000). The map shows the key KOCOA features numbered with a single numerical series. Spatial information obtained by the analysis is presented in the form of two elevation models with symbols that refer to specific historical events in the studied area.

An Historical Digital Elevation Model provided a simplified representation of contemporary topography on maps of the Second Military Survey within the study site. The DEM allowed for the development of contours (contours $1 \mathrm{~m}$ ) on the base map and the viewshed analysis of key observation posts on the battlefield.

\section{Theories and reasoning}

The main reason for creating the study was to confirm the historical reports on the build-up of field fortifications for the Austrian artillery between Kuks and Zaloňov. In many cases, written sources are confused in various pieces of information. The only true source is the analysis of the historical battlefield landscape, which can precede destructive archaeological research or metal detector survey. First, it is necessary to present historical sources for the researched episode of the 1866 war.

\subsection{Historical background}

The war of 1866 was a turning point in European history. Austria should have won the war and secured its future in Europe. In 1866, the mighty Austrian Empire was attacked by the armies of Prussia and Italy. In a quick campaign, the 
Prussians overran Austria's German allies: Hanover, Hessia, Bavaria, and Saxony and then thrust into the Habsburg Kingdom of Bohemia. The Austrian North Army in 1866 totalled 240,000 men. It concentrated in Olmütz in Moravia in June 1866, and immediately commenced a flank march to Bohemia to fight the three Prussian armies invading on an arc from Silesia (Second Army, 115,000 men) through Lusatia (First Army, 100,000 men) to Saxony (Elbe Army,
40,000 men). After the lost important battles of Austrian troops near Trutnov $\left(27^{\text {th }}-28^{\text {th }}\right.$ June $)$, Dvůr Králové nad Labem (29 $9^{\text {th }}$ June), Náchod $\left(27^{\text {th }}\right.$ June) and Česká Skalice ( $28^{\text {th }}$ June), the main Austrian command staff knew they must choose terrain for the retreat to the ideal site for the main battle of the war (Wawro, 1996).

The study site was an especially important strategic position with many high hills on the right bank of the Elbe
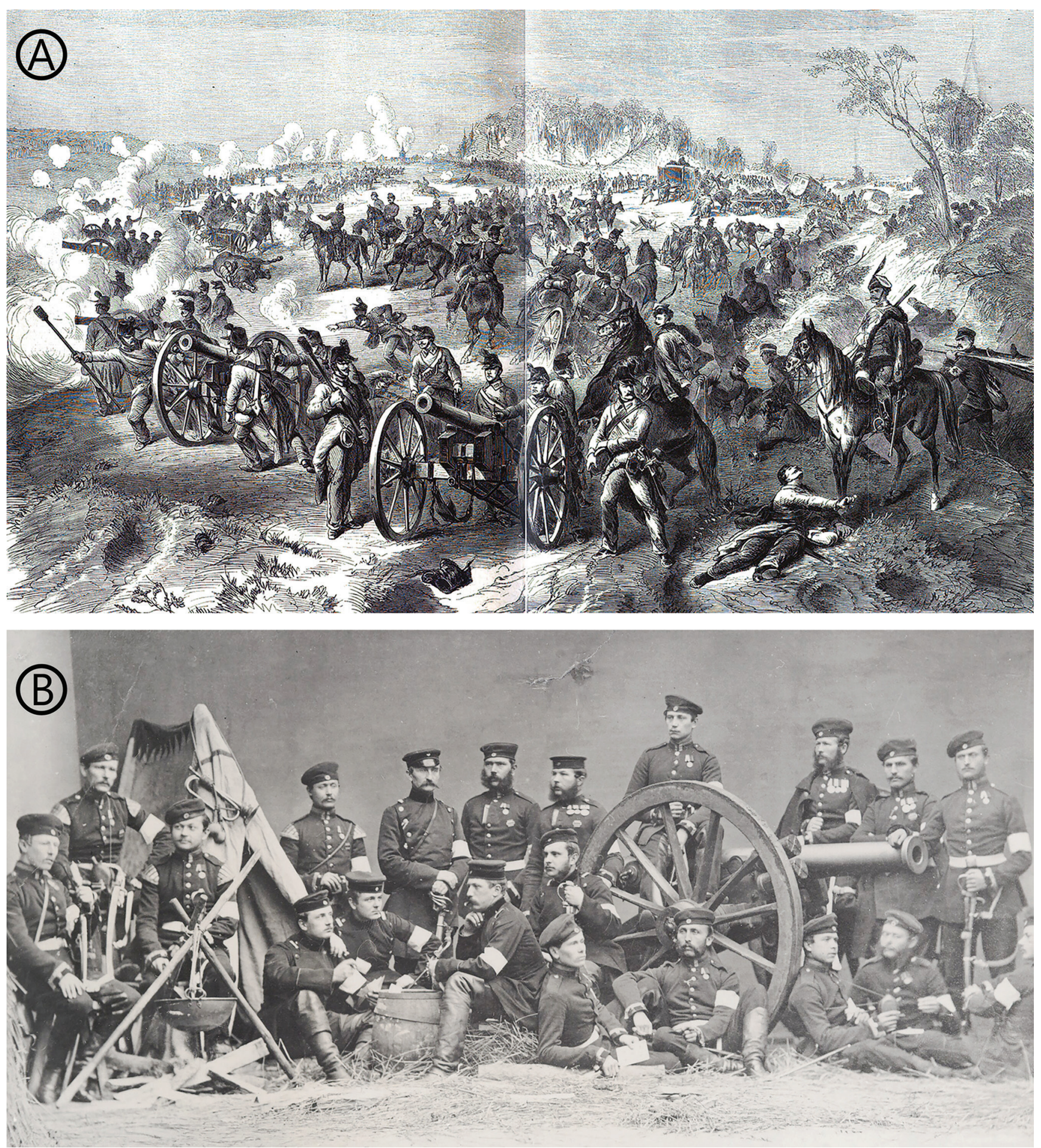

Figure 2. The artillerymen in 1866. A: Firing position of the Austrian field artillery. Sources: Illustrirte Zeitung, 1866; B: The commandants and artillerymen of a Prussian guards battery during the 1864 campaign to Denmark. Sources: Det Kongelige Bibliotek, København, DH017434. 
River. For this reason, Austrian troops moved to these places from 6 am on $29^{\text {th }}$ June with the main aim to stop the Prussian V Army Corps and Guards Corps who marched from the north. The Austrian II Army Corps camped near many villages on the study site over night. The corps built fieldworks on the nearby paths and prepared firing positions for the artillery that should have been deployed against the enemies advancing from the north or east. Württemberg's Brigade camped east of Kašov village, Saffran's Brigade camped behind the buildings of a local pub (Teufelsschenke), and the Thom's and Henriquez's Brigades with artillery corps made their bivouacs near Zalon̆ov (K. K. Generalstabs-Bureau, 1868, pp.191-192). One infantry unit occupied the monastery in Kuks, and two infantry platoons (200 soldiers) captured Slotov and Brod. The commander-in-chief of the Austrian Engineering troops, Colonel von Pidoll, charged two hundred men to dig artillery positions on a hill situated ahead of the army corps. The seven trenches were finished in the next morning (K. K. Generalstabs-Bureau, 1868, p.216).

Brigades of the II Austrian Army Corps started to prepare food in their bivouacs near Zaloňov and Hospital Kuks on the morning of $30^{\text {th }}$ June. The Prussian artillery launched an attack on the Austrian brigades in their bivouacs at 3:30 am. The firing positions of twelve Prussian guns of the V Army Corps were situated on a hill south of Choustníkovo Hradiště. The alarmed Austrian brigades sent eight 4-pounder guns and eight 8-pounder guns for an attack against the Prussian artillerymen, which started around $4 \mathrm{am}$. The commanderin-chief of the Austrian II Army Corps gave the order to occupy strategic terrain locations south of Hospital Kuks and alarmed other brigades. Sixteen guns of the Austrian $2^{\text {nd }}$ Artillery Regiment were taken to firing positions in field fortifications. Other Austrian corps (III and IV) also began to prepare for a battle and occupied the positions near Kašov. All guns of the Austrian II Army Corps were gradually employed in the artillery clash. They fired at the Prussian infantry units positioned near Kuks, Žireč and Drahyně. The Prussian commandant General von Steinmetz gave the order to retreat to Choustníkovo Hradiště and all Prussian units vacated the area around $9 \mathrm{am}$. Some buildings in the town were burnt down, but Prussian units did not move away from their bivouacs. They only observed the enemy on the opposite bank of the river and abided the issues. Austrian brigades returned to their bivouacs at 10 am and waited for an attack all day long. Austrian casualties from the artillery

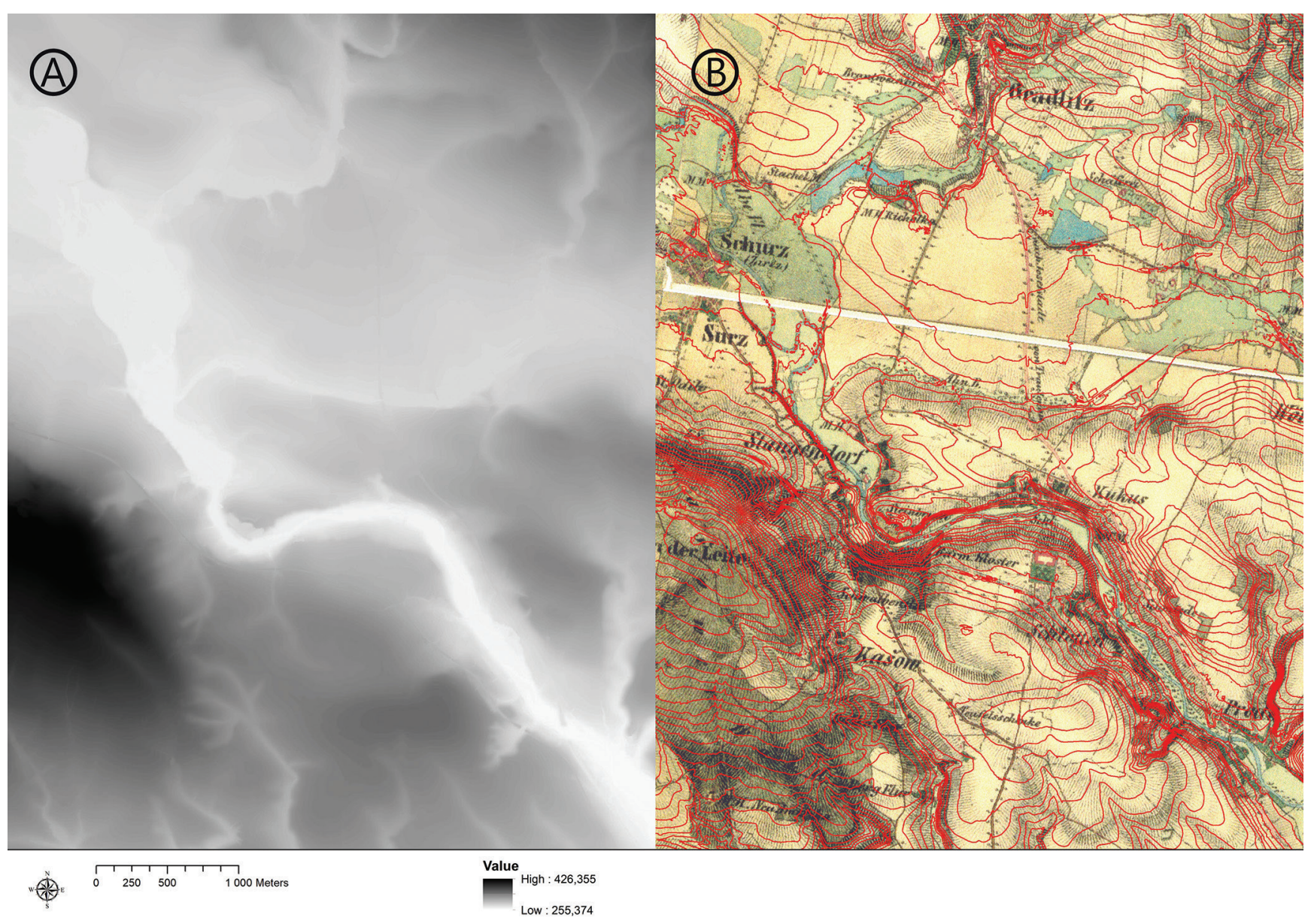

Figure 3. Sources of the analysis. A: Digital Elevation Model representing the current topography of the study site; B: Second Military Survey (1851-1852) of the study site. Sources: Laboratory of Geoinformatics, Faculty of Environment, Jan Evangelista Purkyně University in Ústí nad Labem, Ministry of the Environment of the Czech Republic and Austrian State Archive/Military Archive in Vienna and LIDAR one-metre contours. 
attack were 4 soldiers and 2 horses, 2 officers and 24 men were wounded. The Prussians registered a total of 6 dead and 20 wounded men (K. K. Generalstabs-Bureau, 1868, pp.216-219; Prussian Grosser Generalstab, 1867, p.238).

The command of the Austrian army ordered the retreat to Hradec Králové on the last day of June. The Austrian army was to rest after a quick retreat and wait for the enemy to defeat them in the decisive clash of the war. The advantageous strategic position near Kuks was thus not used to its full extent. The Austrian troops were later defeated near Hradec Králové on $3^{\text {rd }}$ July and some parts of the army had to quickly retreat to the capital of the Monarchy to take defensive positions. Austria's defeat by Prussia expedited the German and Italian unification and accelerated the process of Austrian imperial decline.

The field artillery of the Austrian army was divided into two main groups, namely the light and the heavy artillery.

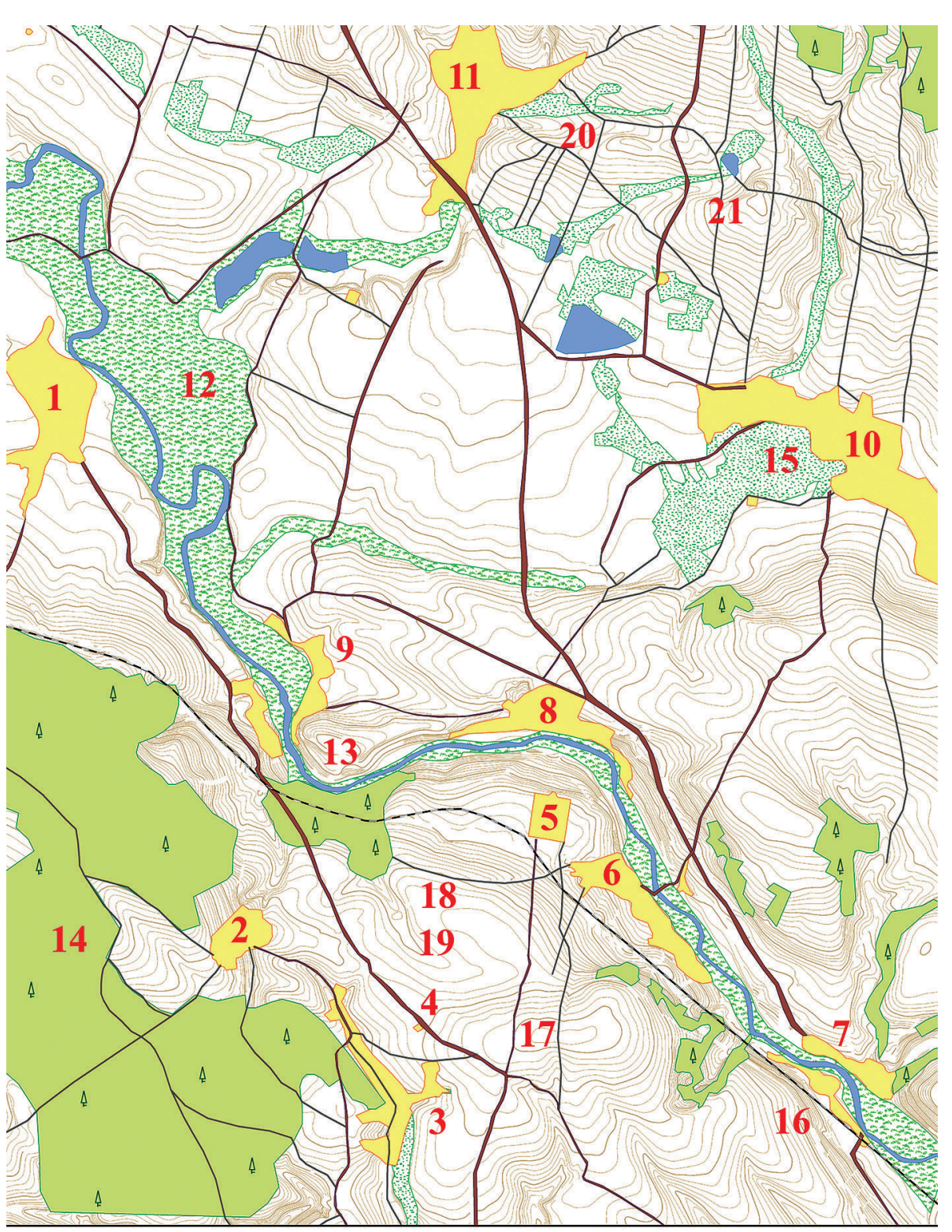

The basic unit was a battery with 8 guns (Figure 2A). Each artillery regiment (83 officers, 3,364 men, 1,615 horses and 88 guns) had 10 batteries and was assigned to an Army Corps. The Austrian cannons model 1863 had a calibre of $8 \mathrm{~cm}$ (four-pounder) and $10 \mathrm{~cm}$ (eight-pounder). Ammunition for cannons model 1863 was prescribed in three variants: grenade, shrapnel shell and grapeshot. The maximum range was 3,800 metres (Müeller, 1864, pp.14-20, pp.205-215).

In a field campaign against the Austrian monarchy, the Prussian army assembled into the artillery regiment only 6 guns in one battery. Their cannons of a new design could be loaded from behind, but their artillerymen were often not sufficiently trained. The most effective was the cannon model 1864 with its 8-cm calibre (four-pounder) and model 1861 with its 9-cm calibre (six-pounder) (Figure 2B). Their ammunition also consisted of grenade, shrapnel shell and grapeshot (Tuhý et al., 2015, pp.415-439).

Figure 4. Base map representing the historical 1866 landscape. 1: Žireč village (Surz); 2: Kašov village (Kašow); 3: Nový Kašov village; 4: position of the Teufelsschenke pub; 5: Hospital Kuks (Kloster Kukus); 6: Slotov village (Schlotten); 7: Brod village (Prode); 8: Kuks village (Kukus); 9: Stanovice village (Stangendorf); 10: Vlčkovice v Podkrkonoší village (Wölsdorf); 11: Choustníkovo Hradiště village (Gradlitz); 12: Elbe River floodplain with meadows; 13: Elbe River; 14: forested location above the Kašov village (Kaschower Wald); 15: meadows; 16: railway track; 17: strategic position " $\mathrm{Na}$ sancich" at a height of $353 \mathrm{~m}$ asl (Schanzen Flur); 18: strategic position above the railway track (Kloster Flur); 19: cover position (Grenzen Flur, Birken Flur); 20: position of the fire range of Prussian artillery at a height of $323 \mathrm{~m}$ asl.

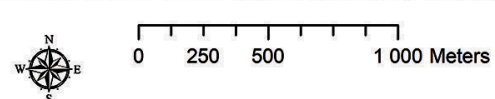




\subsection{KOCOA military terrain analysis}

The basic source used for the reconstruction of the historical landscape was the LIDAR data for the DEM. The data was purchased as part of specific student research at the Department of Archaeology, Philosophical Faculty, University of Hradec Králové. The values were processed and presented with 3D Analyst Tool in the ArcGis software (Figure 3A). The use of LIDAR data helped to derive contours (Figure 3B) for the upland areas on a Second Military Survey map of the study site.

The base map includes all values based on cartographic and historical resources with symbols and numbers for all parts of landscape and spatial data of the military units. The other two maps present the results of analysis of the fields of fire of the Austrian and Prussian guns and analysis of the viewshed from the best observation posts on the top of the two hills. The list describes all elements of the KOCOA analysis with links to the resulting maps.

\subsection{Key terrain}

The basic strongpoints were the villages and homesteads concentrated near the river Elbe and the northerly-situated villages of Choustníkovo Hradiště (Figure 4:11) and Vlčkovice $\mathrm{v}$ Podkrkonoší (Figure 4:10). The wooden buildings in villages provided a good visual shelter from the enemy, but insufficient cover against artillery fire. The only exception was the monumental stone-built complex of the baroque monastery in Kuks (Figure 4:5), which was occupied for this reason, together with the village of Kašov (Figure 4:2), by Austrian infantry patrols on $29^{\text {th }}$ June. At the same time, the Prussian corps captured Choustníkovo Hradiště.

The most strategic terrain locations are situated on the right bank of the river: for example, a wooded plot above Kašov (Figure 4:14) and the hill location "Na šancích" (Figure 4:17). Another ideal position on the right bank was

Figure 5. Viewshed and fire range analyses of Prussian artillery. A: Prussian observation post; B: maximum effective range of Prussian 4-pounder guns $(3.5 \mathrm{~km})$ and 6-pounder guns $(3.8 \mathrm{~km})$.

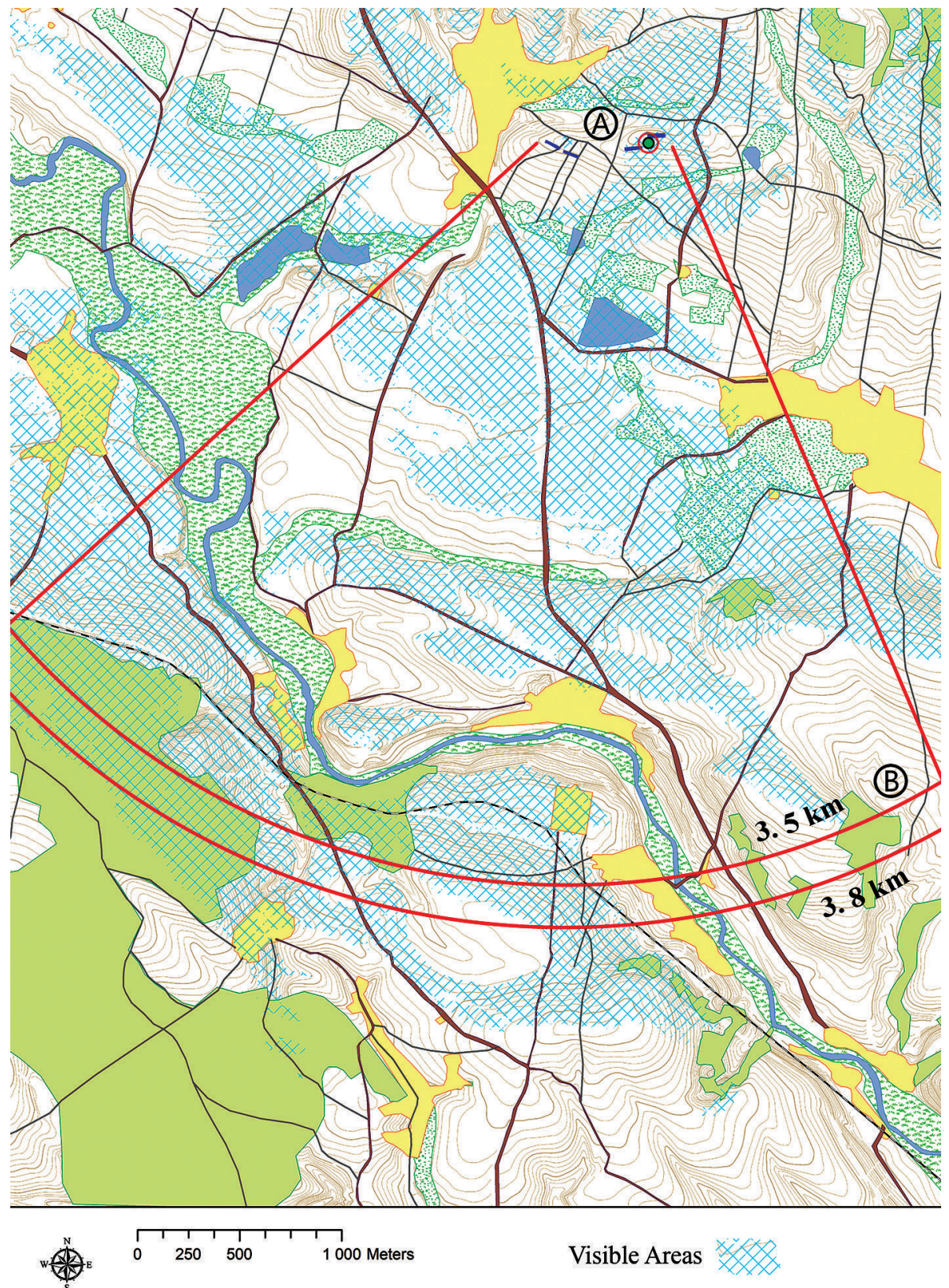


Figure 6. Viewshed and fire range analyses of the Austrian artillery. A: Austrian observation post; $\mathrm{B}$ : maximum effective range of Austrian 4-pounder guns $(3.4 \mathrm{~km})$ and 8-pounder guns $(3.8 \mathrm{~km})$ at the "Na šancích" position; $\mathrm{C}$ : maximum effective range of Austrian 4-pounder guns $(3.4 \mathrm{~km})$ and 8-pounder guns $(3.8 \mathrm{~km})$ at the strategic position above the railway track (Kloster Flur).

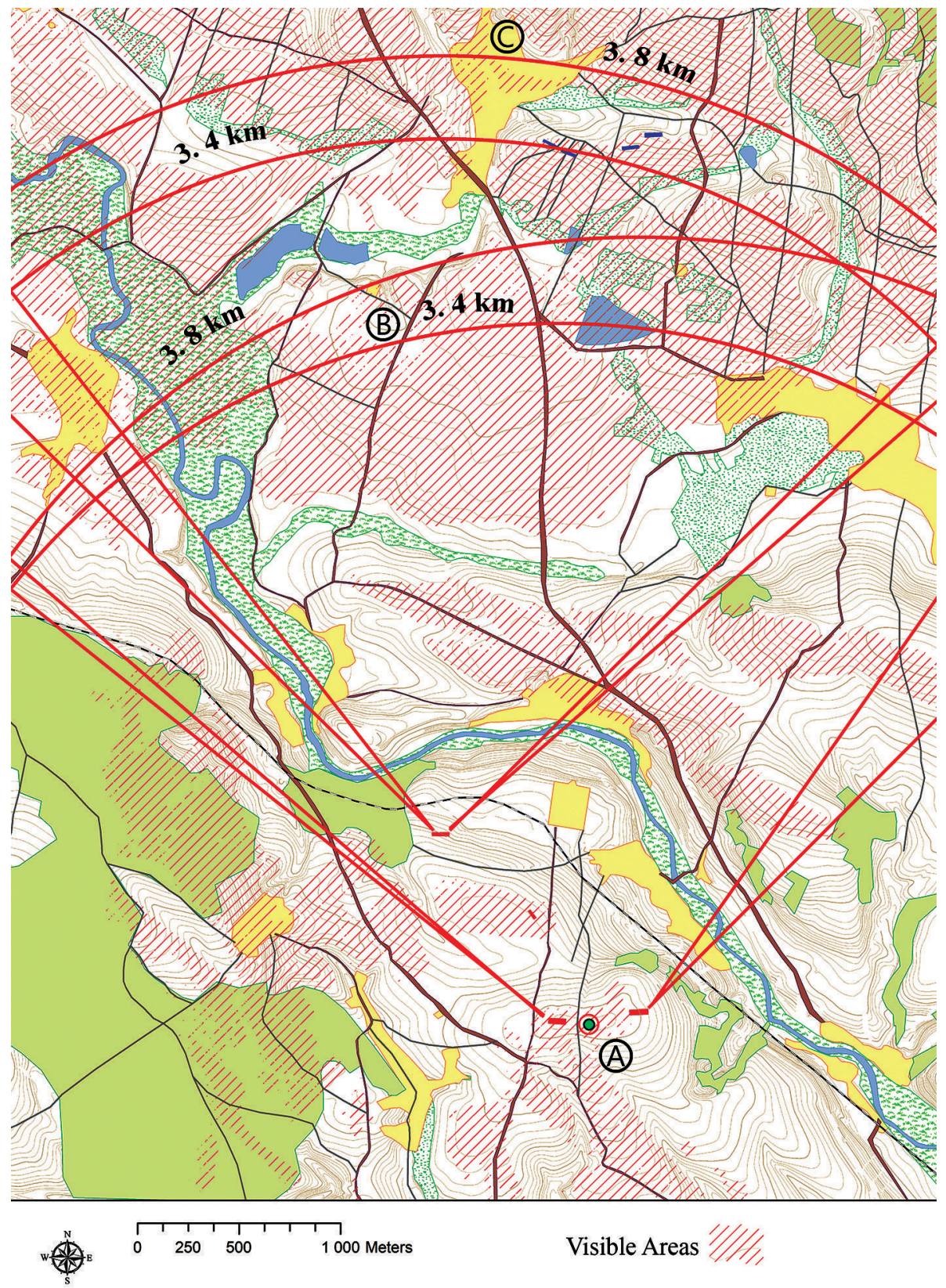

an elevated field situated above the railway (Figure 4:18), which the Austrian troops used as a place for bivouacs before the attacks of the morning of $30^{\text {th }}$ June.

On the left bank of the river, there was only a single strategic location: the small hill (Figure 4:20) situated south of Choustníkovo Hradiště.

\subsection{Observation and Fields of Fire}

The best place for observation (Figure 5A) and target acquisition provided the Prussian artillery with a firing position that enabled them to start an artillery attack on Austrian bivouacs. The maximum firing range of the Prussian six-pounder guns was $3.8 \mathrm{~km}$ (Figure 5B), which allowed the cannons to endanger the areas beyond the railway track near the Hospital.

The above-mentioned Prussian map offers spatial information about the Austrian guns. The closest positions with a possibility to launch an attack on Prussian artillery were located above the railway track (Figure 4:18), where the maximum firing range of the eight-pounder guns reached $3.8 \mathrm{~km}$ (Figure 6C).

The position "Na šancích" provided an excellent line of sight to observe all Prussian positions on the opposite bank of the river. The role of this key terrain feature during an artillery clash and over the whole day was clear, it offered positions for sixteen Austrian guns (Figure 6A) and field fortifications.

\subsection{Cover and concealment}

Cover is protection from the effects of enemy fire and concealment is protection from being observed. The Austrian troops under attack in camp had to find a safe place. The results of the analysis show only one place nearby out of the enemy's firing range. The place was situated north of 
the building called Teufelsschenke (Figure 4:4; Figure 9E). For the Austrian troops it was also possible to use a second position on the right bank of the river Elbe near Stanovice, but this place is difficult to reach.

Prussian artillerymen could retreat behind the terrain wave with their firing positions and they were immediately out of sight of the enemy. However, to get completely out of the firing range of the Austrian guns, they had to retreat to the northernmost edge of Choustníkovo Hradiště, where other Prussian army corps were encamped with their guns in firing positions. Some of the advanced Prussian units later occupied the only covered position situated closer to Kuks behind the hill Schrankberg (Figure 4:21).

\subsection{Obstacles}

The main obstacle for both armies was the river Elbe, with its markedly-profiled riverbed and adjacent waterlogged floodplain meadows (Figures 4:12 and 4:13). The location of the river significantly supported the strategic defensive position of the Austrian II Army Corps. However, a potential serious obstacle for the Austrian artillery was the railway track: because it was difficult to cross.

The Prussians moving forward through the plain between Choustníkovo Hradiště and the river were not hindered by any obstacles, but they did not advance closer to Austrian positions for fear of their heavy artillery fire.

\subsection{Avenues of approach and retreat}

The route which an army can use to reach its objective or withdraw from an area can have a major impact on the course of action and the capabilities of the opposing forces. Field paths and roads provided the fighting armies with ample opportunities for their movements.

Field camps of the Austrian army were usually pitched near paths and the same rule was applied to the movement of guns to firing positions and to the build-up of field fortifications. All paths and roads were used by the artillery with horses to move guns forward and to retreat. Austrian soldiers for their retreat only used open fields, and during the day they probably used all paths to move forward to the vicinity of villages.
Prussian artillerymen used field paths mainly to move guns to firing positions and prepare them for an artillery attack against the Austrian bivouac in the morning of $30^{\text {th }}$ June. They probably used the same paths during the day when they had to retreat to the north. Prussian army corps could have used the main roads for the advancement from Choustníkovo Hradiště to Brod village, but they had to wait for the retreat of Austrian troops in the night of $30^{\text {th }}$ June.

\section{Results of the analysis}

The analysis was intended to provide spatial information that is not apparent from historical or cartographic sources, especially those regarding the Austrian II Army Corps and their bivouacs. Therefore, the analysis is rather focused on the position of the Austrian II Army Corps in the strategically most-advantageous terrain on the right bank of the river Elbe. Infantry units in field camps and artillery units in firing positions with seven field fortifications were to be placed in the most advantageous position in the field.

The combination of fire range and viewshed analysis based on a digital elevation model and base map of the historical landscape in 1866 brought interesting results, which are illustrated on two elevation models with historical events during the artillery clash on $30^{\text {th }}$ June 1866 .

The first phase shows the places of bivouacs of the Austrian brigades of the II Army Corps together with locations of surrounding villages. These areas were located in advantageous positions, which were accessible by roads and were sufficiently large and flat. According to the results of the analysis, the location of the camp of Württemberg's Brigade (Figure 7A) was indeed the only one within the dangerous viewshed and firing range of the Prussian cannons near Choustníkovo Hradiště, because the Prussian artillerymen recognised it well on the horizon.

The second phase on the map shows the deployment of Austrian units after the alarm and the take-up of covered positions (Figure 8). Parts of the infantry units of both brigades moved to the position "Na šancích", which offered the best view and a large firing range for artillerymen

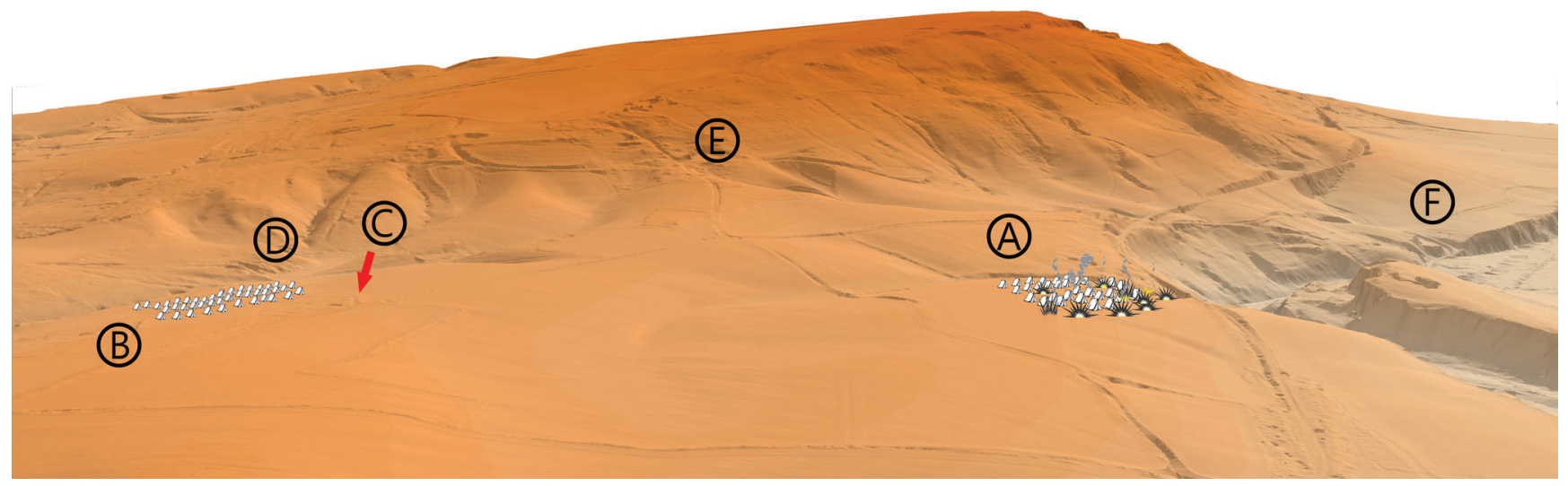

Figure 7. The elevation model displaying the results of the battlefield landscape analysis, location of bivouacs of the Austrian corps. A: bivouac of Württemberg's Brigade under Prussian artillery attack; B: bivouac of Saffran's Brigade; C: position of the Teufelsschenke pub; D: Dolní Kašov village; E: Kašov village; F: Stanovice village. 


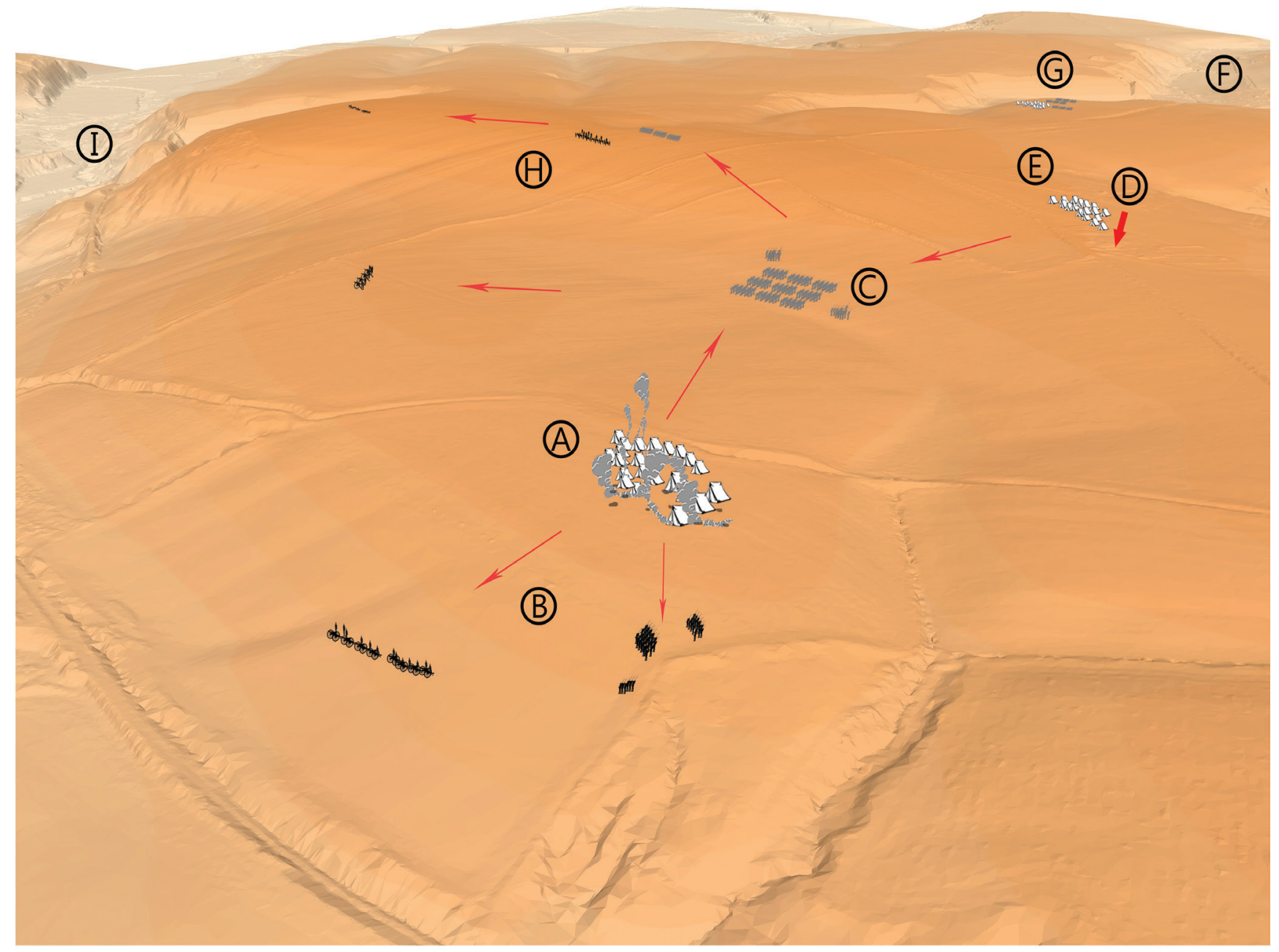

Figure 8. The elevation model displaying the results of the battlefield landscape analysis, positions of Austrian infantry units and guns after Prussian artillery attack. A: abandoned bivouac of Württemberg's Brigade; B: Austrian guns in the strategic position above the railway track (Kloster Flur) and some of the infantry units of Württemberg's Brigade moving to the Elbe River; C: cover position (Grenzen Flur, Birken Flur) with major military forces of Austrian Württemberg's and Saffran's Brigades; D: position of the Teufelsschenke pub; E: abandoned bivouac of Saffran's Brigade; F: Zaloňov village; G: backup units of the Austrian II Army Corps; H: Austrian artillery batteries in the "Na šancích" position with infantry units of Württemberg's and Saffran's Brigades; I: Brod village.

(Figure $8 \mathrm{H}$ ). Moreover, the position was to be fortified by a field fortification already in the morning. Four cannons were also to be deployed below this position, facing further northeast. Patrols of Württemberg's Brigade occupied the forest near Kašov and the right bank of the Elbe towards the monastery building (Figure $8 \mathrm{~B}$ ) to strengthen the soldiers deployed there from the previous day. An artillery battery was to accompany them towards the railway.

The only position that was hidden from the view of the enemy and at the same time was placed out of the range of his guns was used to hide the main forces of Württemberg's and Saffran's Brigades (Figure 8C). Other brigades of the corps remained as a backup before Zaloňov (Figure 8G).

The results of the deployment of these units led to the delineation of a research polygon for the search for the remains of ditches of field fortifications at the position "Na šancích" by means of a geophysical survey. The position is formed by gravel and sand subsoil, which is the only one in the investigated position to protrude from mostly loess soils, which significantly affected the measurement results (Milo, 2019, p.12). The measurement results were markedly affected by oval magnetic anomalies (Figure 10) together with a large number of geological structures such as frost wedges, field plot boundaries or defunct roads.

A markedly positive linear anomaly with a length of 150 metres was noted in the western part of the polygon (Figure 10B). However, this anomaly, with its irregular shape, does not resemble any of the used shapes of the Austrian army fortifications. More likely, however, is a linear anomaly located in the western part of the previous anomaly and which, in addition, shows negative values (Figure 10A) - as was the case with other measurements of relics from 1866. The anomaly's length reaches 30 metres and its width $1.5 \mathrm{~m}$. 

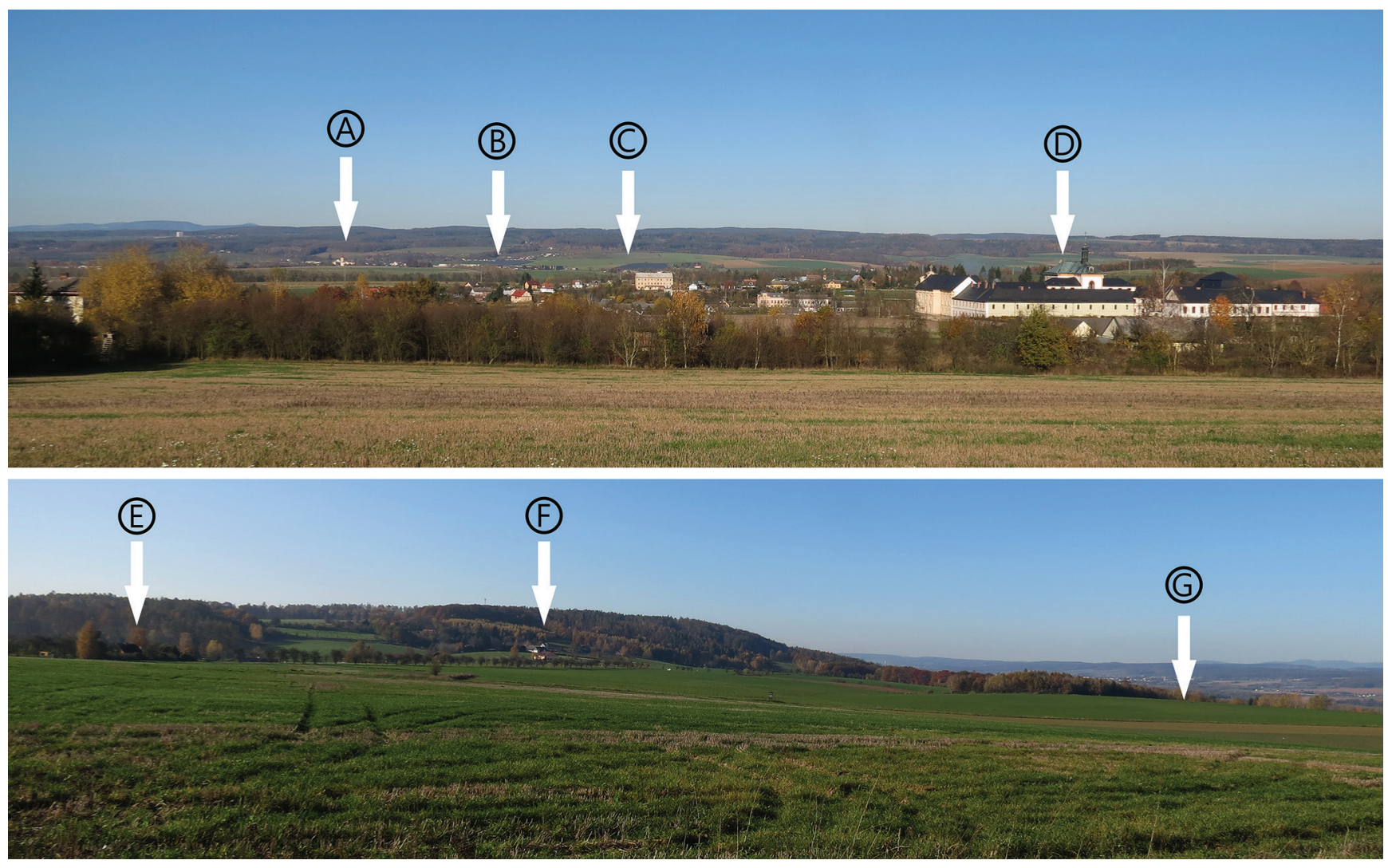

Figure 9. Photographs of the study site from a position above the railway track. A: Choustníkovo Hradiště village; B: position of Prussian artillery; C: cover position (Schrankberg); D: Hospital Kuks; and photographs from the position "Na šancích"; E: position of the Teufelsschenke pub; F: Kašov village; G: bivouac of Württemberg's Brigade.

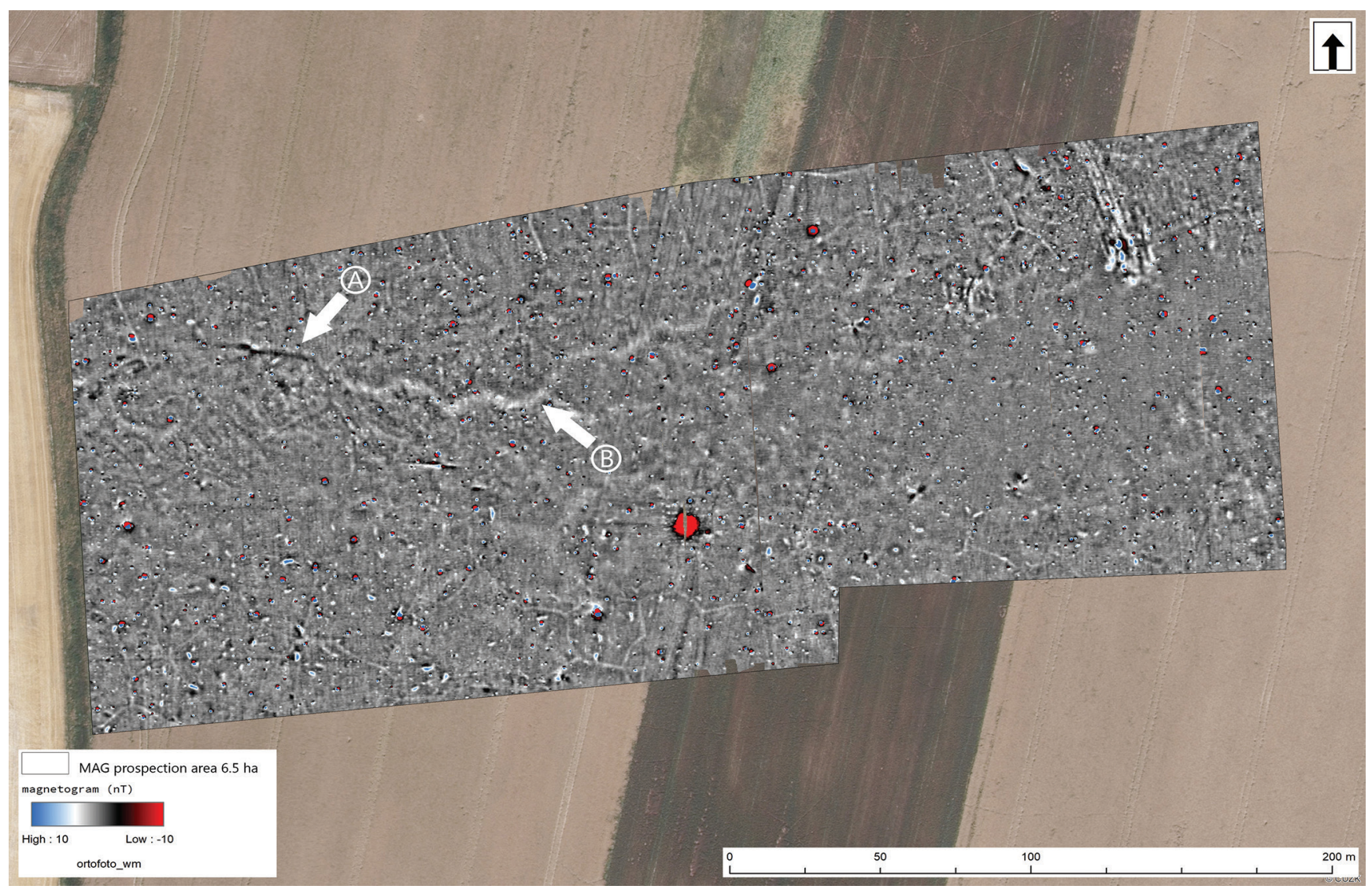

Figure 10. The results of the geophysical survey in the "Na šancích" position. A: regular ditch; B: irregular ditch. 

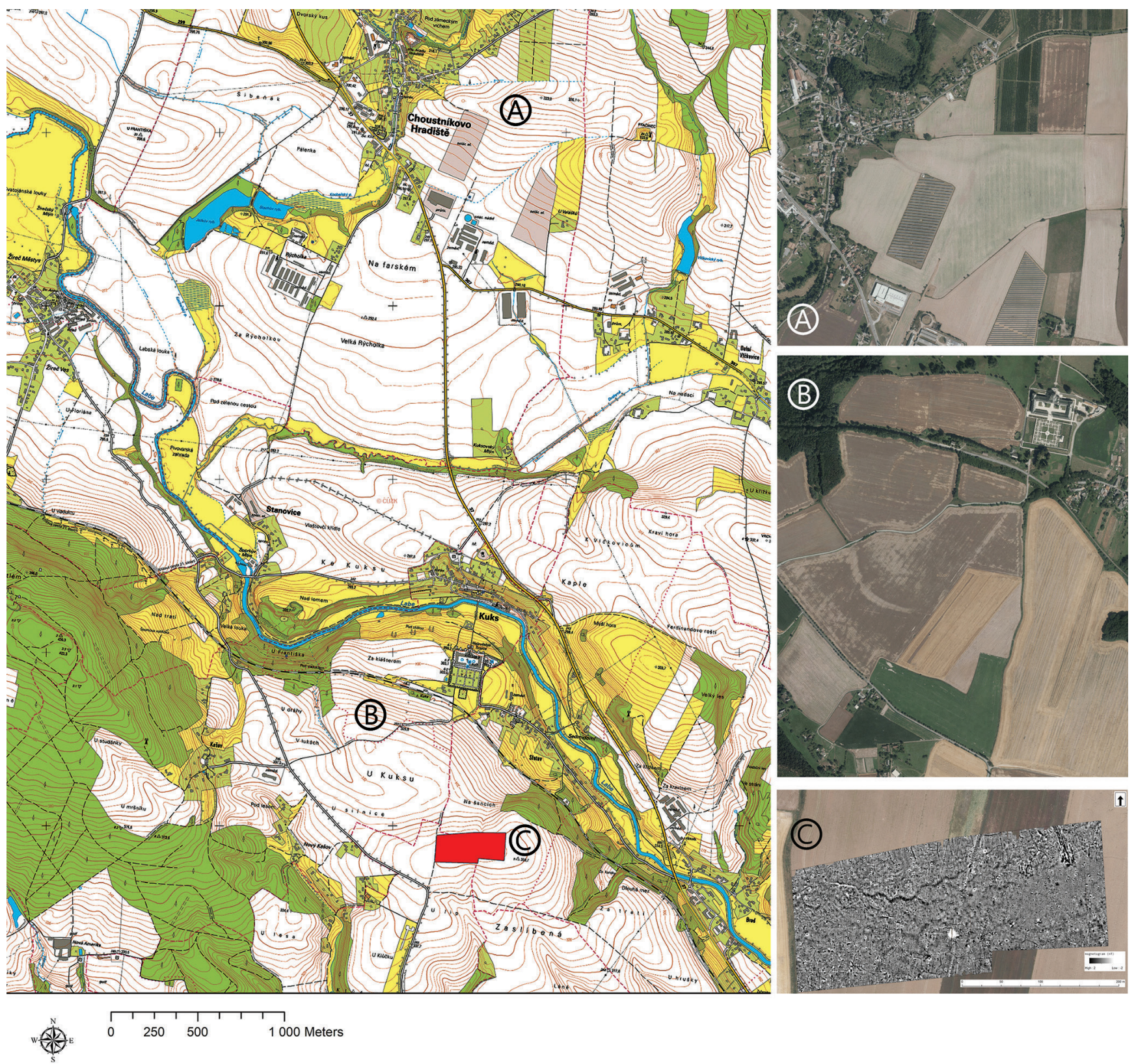

Figure 11. The locations with potential for further research on the study site. A: position of Prussian artillery; B: position of Austrian bivouac attacked by artillery; C: magnetic prospection area and position of Austrian guns.

\section{Discussion}

The analysis of the cultural landscape of the battlefield was approached using the above-described methods due to many discrepancies in the written and cartographic sources. In addition, it confirmed the location of Prussian artillery batteries in the only strategic position near Choustníkovo Hradiště (Figures 9A, B and C). The village was gradually occupied, and camps were built in its vicinity. From no place other than this one, however, was there a better view towards Kašov (Figure 9F) and the terrain wave behind the river. Today, this space consists of plots with arable land and thus ensures the possibility of future detector prospecting (Figure 11A). Confirmation of this position helped to locate the Austrian camp of Württemberg's Brigade (Figure 9G), which was attacked exactly from that position by artillery fire. The location is also formed by arable land and may be subject to detector prospecting in the future.

The most important issue for the analysis was the location of field fortifications for the Austrian artillery. The claim of the Austrian General Staff is not substantiated by a cartographic source and the location of the fortifications is not recorded in the cartographic sources of the Prussian army from 1866. Moreover, the source shows the positions of artillery batteries on the battlefield which were mapped by a Prussian officer after the clash. This means that he was sure that the batteries were indeed there, but he did not depict the fortifications in them. The fact that the written description 
1.

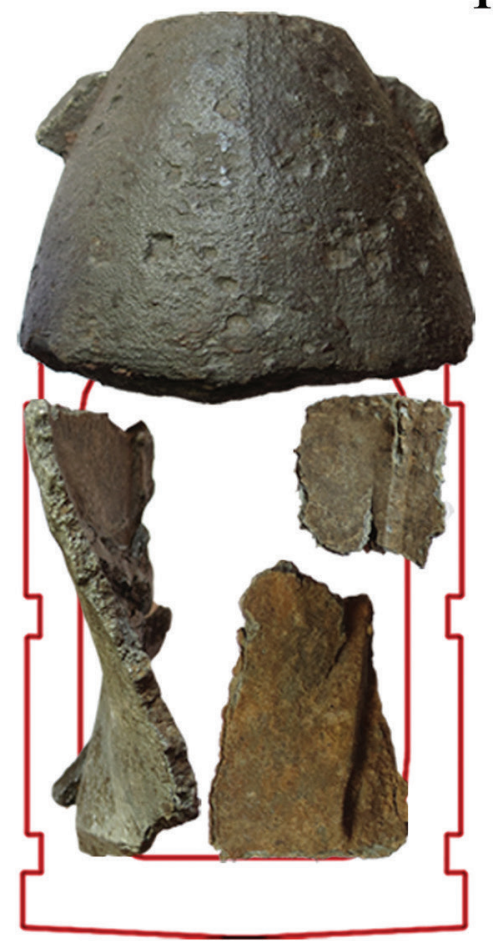

0
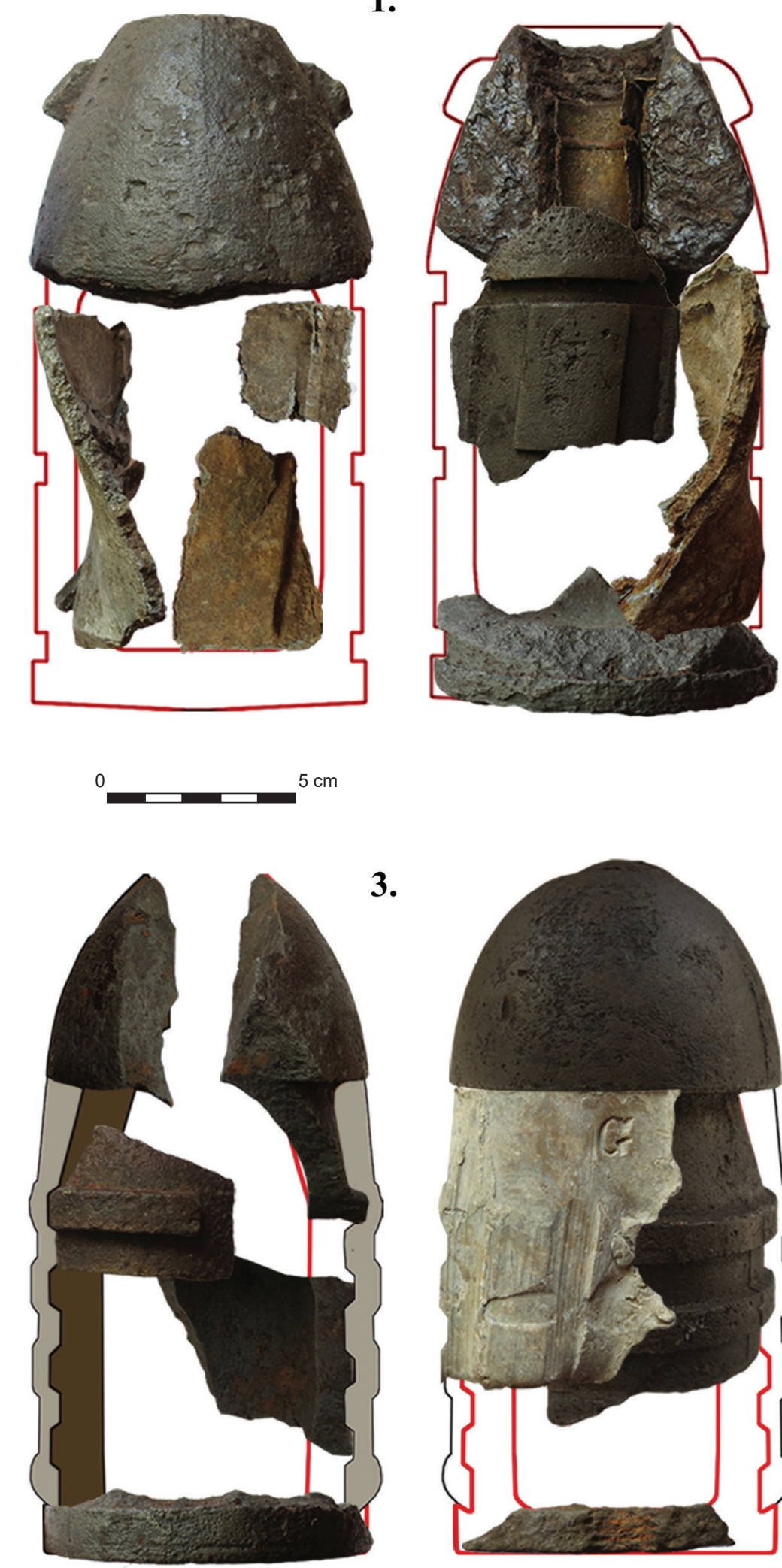

2.

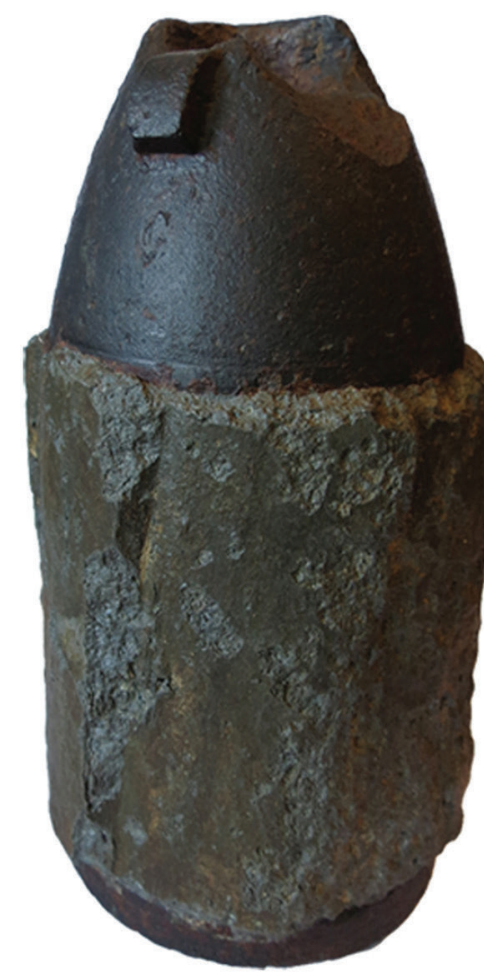

3.

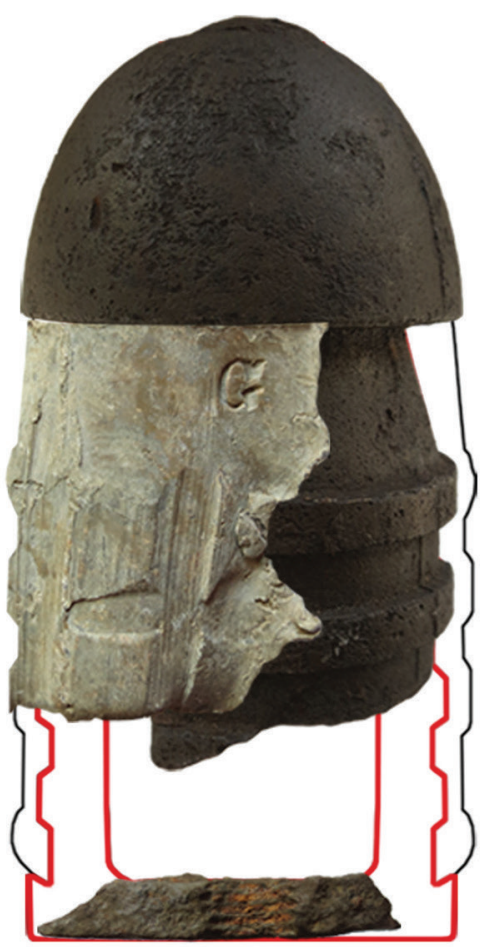

4 .

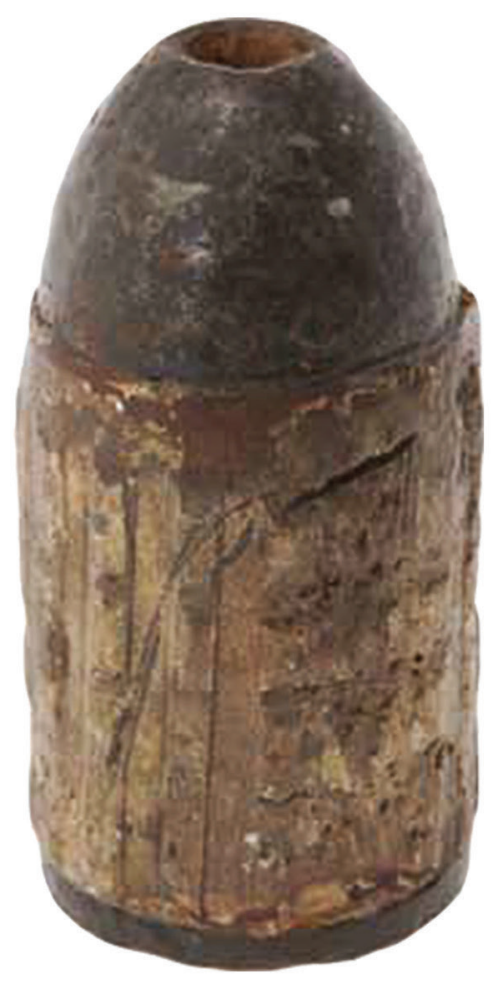

Figure 12. Artillery ammunition from the 1866 battlefields. 1: parts of an Austrian artillery 4-pound grenade; 2: Austrian 4-pound grenade; 3: parts of a Prussian artillery 4-pound grenade; 4: Prussian 4-pound grenade. Stored: 1-3: Muzeum Náchodska, 4: Bayerisches Armeemuseum. 
of Austrian origin on the location of artillery batteries is incompatible with the Prussian cartographic source is far from unique. Similar disagreements can be found in many sources from the entire war of 1866. The absence of the exact time range of the fortification work of 200 Austrian pioneers is also unusual. By the morning of $30^{\text {th }}$ June, a total of 7 fortifications for artillery batteries are reported to have been built on elevated places, which were to support the entire corps in its defensive position. The brigades reportedly used this defensive position in the morning, when they were attacked while cooking in the camp east of Kašov, and later moved to these strategic positions. That this was a strategic advantage for the Austrians is also supported by the way in which the artillery firefight ended, and a further Prussian advance was stopped. However, based on the main decision, the Austrian corps had to leave these advantageous positions and withdraw with the other corps to Hradec Králové.

As part of the site study, geophysical prospecting was aimed at the most advantageous strategic location of the entire site for the Austrian army. According to the analysis of the battlefield, it was supposed to be a place with an ideal view of the entire valley beyond the river to the north with a sufficiently large firing field. The place was to be chosen before the artillery firefight by the head of the engineering department of the Austrian army, i.e., it was supposed to have the most ideal characteristics. In addition, according to a Prussian source, at least two Austrian artillery batteries (16 cannons) were placed in the area, i.e., the potential for the presence of field fortifications on the site was highest.

Unfortunately, geophysical measurements did not confirm with a clear result the location of the relics of the ditches of the Austrian field fortifications for artillery. At the position, two linear anomalies of different values were detected by measurement. Positive values were detected with an irregular zigzag anomaly with a length of 150 metres, whose shape resembled no defensive element for artillerymen from the mid- $19^{\text {th }}$ century. Its origin is therefore more related to geological activities on the site. On its western side, however, there is a linear anomaly 30 metres long and $1.5 \mathrm{~m}$ wide, which could potentially date from 1866. Its shape might correspond to the hastened build-up of a similar fortification feature as it is known from previous research on the battlefield near Hradec Králové, however, the results are currently being further processed.

All positions are by their nature usable for the application of detector prospecting, which could confirm the hypotheses and the whole analysis. In addition, the artillery material (Figure 12) of the guns used is relatively easily identifiable, so it would play an important role in future research.

\section{Conclusions}

Methods and procedures for analysing the cultural landscape of a historic battlefield from the $19^{\text {th }}$ century were for the first time applied to a battlefield of the Austro-Prussian War of 1866. The aim of the analysis was to locate the area of an artillery attack, which took place on the site during the morning of $30^{\text {th }}$ June 1866. Austrian troops were attacked in their field camps by artillery fire from Prussian guns and after their withdrawal to covered positions, an artillery clash took place. Historical sources speak about the build-up of field fortifications, which were supposed to ensure a better strategic position for the defensive stand of the Austrian II Army Corps on the right bank of the Elbe River.

Using the possibilities offered by ArcGis software, the areas from which the fire was conducted, their borders, and the places of Austrian field camps, were marked out. In the modelled landscape, the identified spatial information was visualised into two final elevation models.

This non-destructive method helped to prepare research polygons at a specific location for geophysical measurement. The measurement confirmed a linear anomaly (probable location of a fortification ditch) in the "Na šancích" position, 30 metres long and 1.5 metres wide. Judging from the research carried out on the battlefield near Hradec Králové, it is possible that it may indeed be a relic of a fortification work of the Austrian army.

The results and spatial information may help in future research using metal detector survey or archaeological excavation, which could better confirm the results of this non-destructive analysis.

\section{Acknowledgments}

The article was created with the support of the Specific Student Research of the University of Hradec Králové Prospection of battlefields from the Austro-Prussian War of 1866 in the territory of Hradec Králové Region. Geophysical measurements were carried out by Peter Milo and Tomáš Tencer (Department of Archaeology and Museology, Faculty of Arts, Masaryk University in Brno), and Martin Lanta.

\section{References}

ANONYM, 1864. Prussisk Garde-Batterie [photo]. Deposited in: Det Kgl. Bibliotek, København, ID: DH017434.

AUSTRIA. GENERALSTABS-BUREAU FÜR KRIEGSGESCHICHTE, 1868. Österreichs Kämpfe im Jahre 1866, Wien: Verlag des K. K. Generalstabes, in Commission bei C. Gerold's Sohn, Druck von R. v. Waldheim.

BED, A., 1866. Aus der Schlacht bei Königgrätz: Die österreichischen und sächsischen Batterien bei Problus [engraving]. Illustrirte Zeitung, 47, $240-241$.

ESPENSHADE, CH.T., 2013. Archeological/Historical Research and Military Terrain Analysis of the Credit Island Battlefield (War of 1812), Iowa and Illinois. Commonwealth Cultural Resources Group, Inc., Jackson, Michigan. Submitted to the American Battlefield Protection Program of the National Park Service, Washington, D. C., and City of Davenport, IA.

FANTA, V., 2015. Novověký vývoj krajiny v ochranném pásmu památkové rezervace Kuks podle kartografických pramenů. Průvodni zpráva ke specializované mapě s odborným obsahem v rámci programu $M K \check{C} R$ NAKI (DF11P01OVV027). Praha: Fakulta životního prostředí, Česká zemědělská univerzita v Praze.

GOJDA, M., JOHN, J., STÁRKOVÁ, L., 2011. Archeologický průzkum 
krajiny pomocí leteckého laserového skenování. Dosavadní průběh a výsledky prvního českého projektu. Archaeological remote sensing by means of airborne laser scanning. Interim report upon the first lidar research project in Bohemia. Archeologické rozhledy 63(4), 680-698.

HEJHAL, P., HOLAS, M., 2018. Archeologický nedestruktivní průzkum dělostřeleckých polních opevnění na královéhradeckém bojišti. In: Mlhy na Chlumu. Prusko-rakouská válka v optice moderni historiografie. Hradec Králové: Muzeum východních Čech, Filozofická fakulta Univerzity Hradec Králové, p. 5.

HOLAS, M., 2017. Interpretace stavu výstroje padlých z prusko-rakouské války roku 1866 ve chvíli pohřbení do hromadného hrobu nedaleko České Skalice (okres Náchod). Interpretation of the state of the equipment of soldiers killed in the Austro-Prussian War of 1866 at the time of interment in a mass grave near Česká Skalice (Náchod district). Archaeologia historica, 42(1), 297-317.

HOLAS, M., 2019. Archeologie prusko-rakouské války z roku 1866. Hradec Králové: Pavel Mervart.

KNOWLES, A.K., 2005. Emerging trends in historical GIS. Historical Geography, 33, 7-13.

KRAJÍC, R., MĚŘÍNSKÝ, Z., VAŘEKA, P., 2017. Archaeology of the 16th-20th century in the Czech Republic. Archaeologia historica, 42(2), 367-399.

LOESECKE, 1866. Plan des Gefechtsterrains bei Gradlitz [map]. Available from:http://digitool.is.cuni.cz/R/?func=dbin-jump-full\&object_id=1041504, retrieved on $4^{\text {th }}$ May 2020.

MAIO, CH.V., TENENBAUM, D.E., BROWN, C.J., MASTONE, T.V., GONTZ, A.M., 2013. Application of geographic information technologies to historical landscape reconstruction and military terrain analysis of an American Revolution Battlefield: Preservation potential of historic lands in urbanized settings. Journal of Cultural Heritage, 14(4), 317-331.

MATOUŠEK, V., 2017. Archaeological Research into Battlefields and Military Action in the Czech Lands in the Early Modern Age. History, state of knowledge, discussion. Archaeologia historica 42(1), 233-243.
MATOUŠEK, V., SÝKORA, M., 2018. Válečné události 17.-19. století $z$ interdisciplinární perspektivy. Praha: Toga.

MILO, P., TENCER, T. et al., 2019. SPRÁVA O GEOFYZIKÁLNOM PRIESKUME. Geomagnetická prospekcia, správa 19022, Zaloňov Na šancich. Brno.

MÜELLER, F., 1864. Das österreichische Feld- und Gebirgs-ArtillerieMaterial vom Jahre 1863. Wien.

NOVÁK, P. et al., 1992. Syntetická půdní mapa České republiky. Praha: MŽP.

PREISS, P. 2003. František Antonín Špork a barokni kultura v Čechách. Praha: Paseka.

PREUSZ, M., 2019. Historicko-archeologický výzkum doby třicetileté války (1618-1648). Současný stav studia a perspektivy. The historical and archaeological investigation of the period of the Thirty Years' War (1618-1648). The current state of research and its perspectives. Archaeologia historica, 44(1), 151-183.

PRUSSIA (GERMANY). ARMEE. GROSSER GENERALSTAB. KRIEGSGESCHICHTLICHE ABTEILUNG II., 1867. Der Feldzug von 1866 in Deutschland. Berlin: E. S. Mittler.

SMRŽ, Z., HLUŠTíK, A.J., 2007. Polní opevnění z roku 1813 mezi Postoloprty a Budyní nad Ohř́: výsledky letecké prospekce a historického bádání. Field fortifications dating from 1813 between Postoloprty and Budyně nad Ohř́: results of aerial prospecting and historical research. Archeologické rozhledy, 59(4), 713-746.

STORZ, D., HOHRATH, D., eds., 2016. Nord gegen Süd: Der Deutsche Krieg 1866. Kataloge des Bayerischen Armeemuseums, vol. 13. Ingolstadt: Bayerisches Armeemuseum.

TUHÝ, B., ŠRAMAR, J., ŠRÁMEK, J. et al., 2015. Prusko-rakouská válka roku 1866: Výzbroj a výstroj = Preußisch-Österreichischer Krieg von 1866: Waffen und Ausrüstung = The Austro-Prussian War 1866: Weaponry and equipment. Hradec Králové: Muzeum východních Čech.

WAWRO, G., 1996. The Austro-Prussian War. Austrian's War with Prussia and Italy in 1866. Cambridge: Cambridge University Press. 
